\title{
DOCUMENTARY
}

\section{In the right place at the right time}

\section{Guns, Germs and Steel}

directed by Tim Lambert

National Geographic Television \& Film, premiered on PBS in the United States on 11,18 and 25 July.

Also available on DVD in North America.

\section{Henry Gee}

One day on a trip I took to Kenya in 1998, the cook was suffering a bout of malaria so we had to fend for ourselves. The local Turkana were immune to the disease, but nearly all of those from elsewhere - including the cook, from the malaria-free highlands around Nairobi were susceptible. The cook was right as rain the next day, but millions of Africans are less fortunate.

In some parts of the continent, malaria remains the biggest killer of children under five. To be moved by a bald statistic such as this, we have to be confronted with the reality on the ground, as polymath and prizewinning author Jared Diamond found when he visited a hospital in Zambia - where children were dying all around him.

"There's a difference between understanding something intellectually and experiencing it firsthand," says Diamond, who was filming a TV adaptation of his book Guns, Germs and Steel (Norton, 1997). "In my book, 'germs' was one of the three main forces of history, and it's impersonal, and it's still a different entity... it hits me to be in a place where germs are in action."

Diamond's 'guns, germs and steel' theory is economic geography at its grandest, and like many such ideas, emerged from a small event. Diamond has been a regular visitor to Papua New Guinea since the 1960s, where he watches the birds and, by extension, the people. He has found that despite their stone-age technology, New Guineans are at least as resourceful as Westerners. So why is it that the world is dominated by Europeans, rather than another group? It took a question from a New Guinean to coalesce the problem in Diamond's mind: "Why is it that you Westerners have so much cargo, when we New Guineans have so little?" It took 30 years for Diamond to formulate his response: Guns, Germs and Steel.

According to Diamond, cultures succeed not by the inherent cleverness of their people, but by the luck of geography and biology. Western civilization started 10,000 years ago in the Middle East, which happened to host the wild plants and animals that were the easiest and most productive to domesticate. Based on wheat, cattle and sheep, this civilization spread throughout the temperate regions of Eurasia. The other civilizations it met were isolated by geography, so they could not spread, and had fewer domesticable species - in the case of the

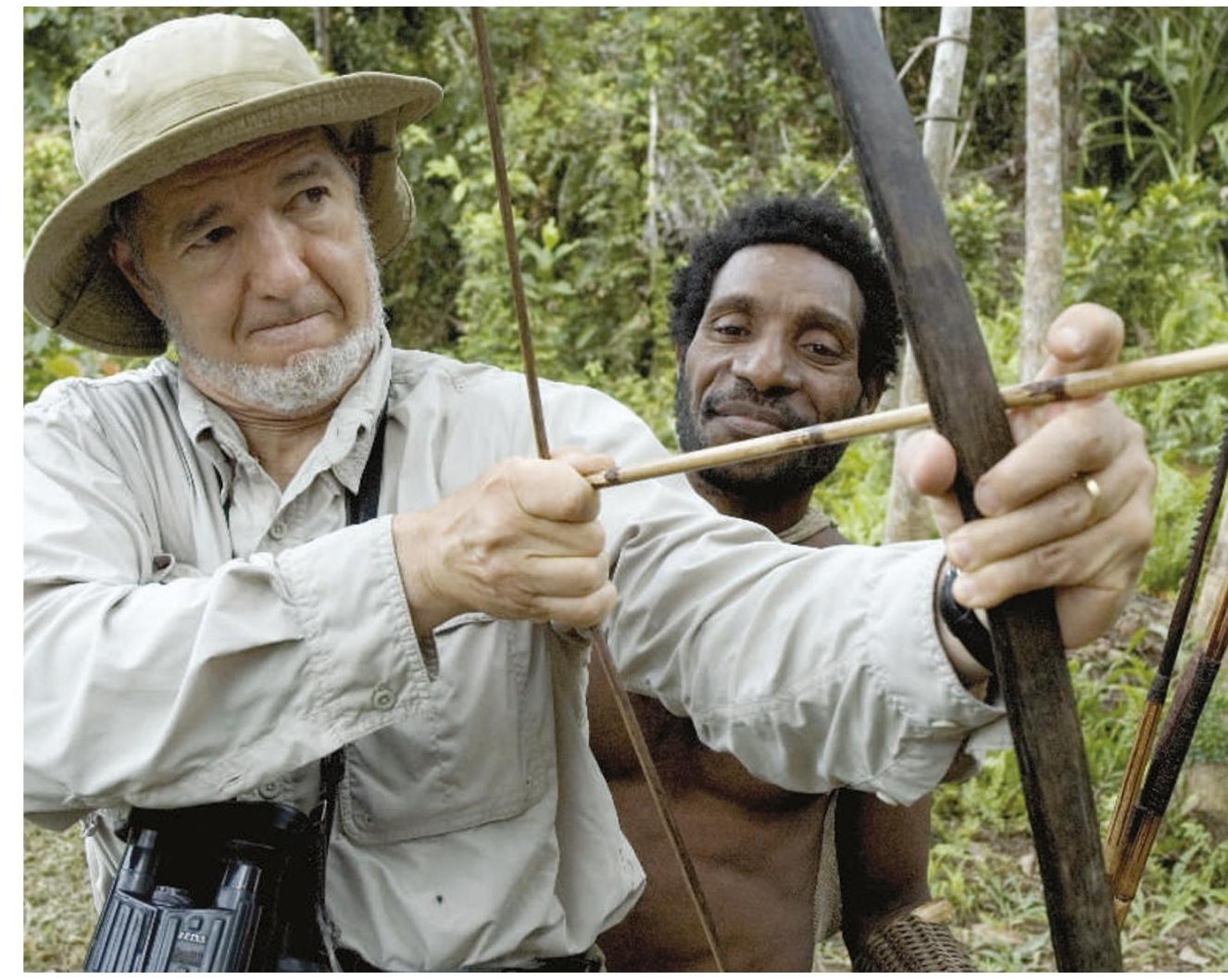

On target: Jared Diamond believes accidents of geography determine a society's progress.

farmers of the New Guinea highlands, so few that the surplus needed to support non-farming members of society could never be achieved. For them, technology would always be out of reach, as would resistance to diseases such as smallpox that owe their origins to long association with domestic animals.

This is why tiny groups of sword-wielding, gun-toting, horse-riding, smallpox-carrying but otherwise unremarkable Spanish adventurers wiped out the Inca and Aztec civilizations within a few years; how a few Boers with muzzle-loading rifles destroyed the mighty Zulus and Matabele in less time - in the great sweep of history - than it takes to make a cup of bush tea; and why you are reading this article in English rather than Nahuatl.

But whenever European settlers in southern Africa strayed north, their advantages gave out. European-style crops would not grow in the less temperate climate, and they and their animals wasted away from tropical diseases. The Bantu farmers they met were unaffected, having built their success in a durable but diffuse civilization that stayed away from rivers or large population centres, and had thus reached an understanding, if not an equilibrium, with disease. The colonial imposition of railroads and large cities eventually destroyed all that, which is why modern Africans now suffer from the ills that were once much less of a problem, and why - in the final part of this three-part series - we see Diamond break down in a hospital in Zambia.

Not everyone will agree with Diamond's thesis. It stems from a new view of history that condemns concepts such as 'manifest destiny' as narrow or racist, and is prepared to examine 'counterfactuals' - scenarios of what might have happened, had the starting conditions been different. But if the new school of history teaches us a lesson, it is that once one understands the reasons for one's predicament, they can be transcended. Singapore and other tropical, southern Asian countries prone to disease, have overcome these obstacles to become big players in twenty-first century technology. Perhaps Africa might follow.

The three hour-long programmes are as beautifully shot as you would expect from National Geographic, but the first two and a half hours are too leisurely, making the final half-hour far too hasty. And although the actor Peter Coyote does a fine job as narrator, having Diamond play second fiddle in his own orchestra prevents Guns, Germs and Steel from achieving the magisterial air of similar programmes that have become classics. Would Alastair Cooke's America have been half as good had Dan Rather narrated it, with Cooke himself in a walk-on part?

Henry Gee is a senior editor at Nature 